УДК 32:316.324

https://doi.org/10.34142/24130060.2019.17.1.01

\title{
КРИЗА ІНСТИТУТУ ДЕМОКРАТІЇ В УМОВАХ ГІБРИДНОЇ ВІЙНИ: ЕЛЕКТОРАЛЬНИЙ РАКУРС
}

\author{
Т.Г. Андрісвський
}

Харківський національний педагогічний університет імені Г.С. Сковороди

В статті розглянуто вразливість демократичних держав в умовах гібридної війни крізь призму проблематики політичних інститутів та прочесів. Визначено, що Російська Федерація у своєму поширенні гібридних загроз приділяє особливу увагу інституту прямої демократії - виборам як головному процесу функиіонування держави. За допомогою дезінформаційних кампаній, маніпулюючи демократичними цуінностями та принципами, агресор намагається послабити опонентів, підірвати політичні системи зсередини та посилити напругу та поляризацію в суспільстві. популізм.

Ключові слова: Гібридна війна, вибори, демократія, російсько-українська війна,

\section{КРИЗИС ИНСТИТУТА ДЕМОКРАТИИ В УСЛОВИЯХ ГИБРИДНОЙ ВОЙНЫ: ЭЛЕКТОРАЛЬНЫЙ РАКУРС}

\section{Т.Г. Андриевский}

В статье рассмотрено уязвимость демократических государств в условиях гибридной войны сквозь призму проблематики политических институтов и процессов. Определено, что Российская Федераџия в своем распространении гибридньх угроз уделяет особенное внимание институту прямой демократии - выборам як главному процессу функционирования государства. При помощии дезинформачионных кампаний, манипулируя демократическими иенностями и принципами, агрессор пытается ослабить оппонентов, подорвать политические системы изнутри и усилить напряжения $u$ поляризаџию в обществе.

Ключевые слова: Гибридная война, выборы, демократия, российско-украинская война, популизм.

\section{CRISIS OF THE INSTITUTE OF DIRECT DEMOCRACY IN THE CONDITIONS OF HYBRID WAR: ELECTORAL ASPECT}

\section{T. Andriyevskyy}

In this article the vulnerability of democratic states in the context of a hybrid war through the prism of political institutions and processes was considered. It is determined that the Russian Federation in its dissemination of hybrid threats pays special attention to the institute of direct democracy - elections as the main process of state functioning. Through disinformation campaigns and manipulations with democratic values and principles, the aggressor tries to weaken the opponents, undermine political systems from the inside, and exacerbate tension and polarization in society. The article analyzes the publication of the adviser to the president of the Russian Federation, Vladislav Surkov, in which the unequivocal threat to the Western democratic 
world order is expressed. An analysis of the statements of Surkov showed that modern liberal democracy is an extremely vulnerable mechanism, where the Russian Federation spreads chaos by manipulating. The aggressor focuses on the erosion of confidence in the government and the strengthening of populism. A similar result is achieved by spreading misinformation and manipulating information. It has been established that misinformation is intended to create an appropriate public opinion, which should correspond to the goals of the aggressor. It is established that the aggressor is interested in the elections as a process, and therefore the victory of a particular (pro-Russian) candidate is not so important for aggressor's purposes. Therefore the process of voting is bringing to the point of absurdity, which would entail doubts about the result of such a procedure. Accordingly, the final result of such elections will be a political system without voter's confidence. Narratives that are "thrown" into the information field are designed to disorient the voter as much as possible, to polarize society, which ultimately should cast doubt on the effectiveness of the electoral process. Therefore, Russian propaganda, through various channels, simultaneously criticizes all the political forces, even opposing in its ideology, or supports some of them (e.g. far-right or far-left populist movements).

Keywords: Hybrid war, elections, democracy, Russian-Ukrainian war, populism.

Постановка проблеми. Гібридна війна 3 притаманними їй спотвореними гібридними цінностями, переповненим фейками інформаційним простором, непередбачуваністю та асиметричністю підривних дій супротивника, на жаль, 3 кожним роком стає все більш звичною і невід'ємною реальністю не тільки для України, але й для Європи. Вищезазначені аспекти гібридної війни вражають практично усі політичні інститути держави, а враховуючи фактор асиметричності, можна цілком припустити, що під загрозою знаходяться усі інституції держави і суспільства.

Аналіз актуальних досліджень. Проблематика феномену гібридної війни досліджувалася як зарубіжними теоретиками (М. Бонд, В. Герасимов, Ф. Гоффман, Р. Гейтс, Р. Гленн, К. Касапоглу, М. Кофман, Дж. Мак К'юен, М. Роянськи та ін.), так і вітчизняними дослідниками (В. Горбулін, О. Їжак, Є. Магда, І. Рущенко, М. Требін, Г. Яворська та ін.).

Мета статті - дослідити та актуалізувати питання вразливості інституту прямої демократії, зокрема виборів, перед дезінформацією та маніпуляцією інформації в умовах гібридної війни.

Виклад основного матеріалу. Політичні інститути та процеси в Україні піддавалися впливу гібридних загроз не тільки протягом усієї російсько-української гібридної війни, але й до початку агресії Російської 
Федерації проти України. Якщо використовувати підхід Нобелівського лауреата Дагласа Норта (2000, с. 12-15) до виокремлення в політичних системах інституцій як сукупності правил і обмежувальних норм та організацій як органів та акторів, то ціллю Російської Федерації була максимальна інтеграція України у свою сферу впливу шляхом інтенсивного залучення політичних організацій у свої політичні та економічні проекти.

Ще до початку Революції Гідності впливу гібридних загроз зазнала українська політична система - в першу чергу через наявність проросійських політичних партій, які пропонували максимальну інтеграцію в російський політико-економічний простір (Горбулін ред., 2017, с. 256-260). У рамках своєї діяльності такі партії також просували наративи по дискредитації самої можливості і необхідності європейської інтеграції, участі у західних військово-політичних альянсах тощо. Для продовження такої діяльності також використовувався вплив недержавних організацій. Серед громадянського суспільства діяла розгалужена мережа громадських організацій, наукових та аналітичних центрів, які за фінансової підтримки Російської Федерації повинні були просувати ідеї «триєдиного народу», «слов’янського братства», «Росії як старшого брата» тощо.

Інтеграція російського дискурсу в українську політичну реальність підкріплювалася відвертими загрозами національній безпеці - в тому числі інтеграція російських або проросійських акторів в інститути національної безпеки (Рущенко, 2015, с. 54-55). Влив і присутність російських агентів впливу у Збройних силах, Службі безпеки, Міністерстві внутрішніх справ, інших воєнізованих формуваннях поступово зменшували можливість здійснення ефективного опору у разі агресивних дій з боку Росії, а також підривали лояльність службовців цих органів Українській державі як такій.

На момент початку Революції Гідності склалася ситуація, коли майже усі головні політичні інститути України були «заражені» - тобто так чи інакше зазнали впливу Росії. Якщо головні інститути, в нашому випадку інститут президента, парламент із пропрезидентською більшістю, а також 
сформовані цими інститутами уряд та центральні органи виконавчої влади зазнали російського впливу, то, повертаючись до класифікації Д. Норта, інституції (як правила функціонування системи) теж зазнали змін. Правова система була вразливою до викликів, i там, де законодавство повинно було захищати національні інтереси - воно або було відсутнім, або мало суттєві прогалини, або відображало інтереси РФ. Так, наприклад, Воєнна доктрина в редакції 2012 року стверджувала Україну виключно як позаблокову державу i3 перспективою максимального скорочення чисельності військовослужбовців (Адміністрація Президента України, 2012). Таким чином, в політичній системі і організації, i інституції формували порядок денний та визначали вектор розвитку держави, який не відповідав інтересам України як суверенної та незалежної держави.

В сфері освітньої та культурної політики відбувалося дублювання цінностей так званого «русского мира» iз запозиченням наративів про «Велику вітчизняну війну» як наріжного каменя i головного міфу у формуванні єдиного суспільства, про протистояння із Заходом і НАТО, про існування в Україні «фашистів та бандерівців» як зрадників. Піддавався сумніву сам факт існування єдиного народу шляхом протиставлення правильних українців (східних) неправильним (західним) та навпаки. Культивувалася ностальгія за СРСР задля створення непривабливого образу незалежної України, утвердження суверенної України як «штучної» квазідержави. Міфічний образ СРСР поступово проектувався на образ сучасної Російської Федерації як його єдиного правонаступника. Український культурний продукт був неконкурентоспроможним і не отримував належної державної підтримки, а тому програвав російському продукту (Горбулін ред., 2017, с 244-245). Мовне питання було предметом постійних штучних спекуляцій для нагнітання та розколу народу. Найбільша релігійна організація прямо підпорядковувалася та мала свої центри управління в Росії. Всі ці інституції - освіта, культура, релігія - покликані формувати ціннісну 
та світоглядну систему індивідів. I вони дійсно формували світогляд українців - як невід’ємну частину «русского мира».

Загалом, головним завданням було сформувати серед українських громадян систему цінностей, максимально схожу на систему, побудовану в Російській Федерації. В такому разі подальше «поглинання» України зазнавало б меншого супротиву та відповідало б природі та меті гібридної війни - позбавленні протиборчої сторони фактичного суверенітету без захоплення всієї території держави, що неодноразово підтверджувалося головним теоретиком сучасної гібридної війни Валерієм Герасимовим (2015).

Аналізуючи загальносвітові тенденції у політичних протистояннях держав на фоні російсько-української гібридної війни, в попередніх дослідженнях автор сформулював ціль цієї гібридної війни, яка полягає в створенні хаосу, підриві цінностей демократичного свіму і культивації всеохоплюючої атмосфери недовіри та нігілізму (Андрієвський, 2018, с. 107). Послабити жертву агресії та підірвати ії політичний устрій агресору значно дешевше, ніж проводити повномасштабну військову операцію. Відповідно, ця ціль досягається деконструкцією політичних інститутів.

Як показали події останніх років, у стратегії гібридної війни почали окреслюватися очевидні пріоритети. Логічно, що якщо агресор має своїм завданням декоснтрукцію політичних інститутів, зниження довіри населення до цих політичних інститутів та процесів, їх делегітимізацію, а заразом і максимальне поширення хаосу - потрібно починати із найважливішого та найефективнішого інституту демократичного світу - інституту прямої демократії, тобто виборів.

У демократичних режимах вибори як вільне волевиявлення народу $є$ відправною точною у функціонуванні всіх політичних процесів держави. Саме на них формується і закріплюється порядок денний та фактичний курс розвитку держави на наступні декілька років. А від того, які актори приходять до влади та легітимізуються на виборах, залежить внутрішня i 
зовнішня політика. Саме тому дестабілізація виборчого процесу $є$ надзвичайно важливим стратегічним питанням ведення гібридної війни.

Війна XXI сторіччя за своїм технічним потенціалом, розвитком військової промисловості, наявності ядерної зброї тощо є тотальною, нищівною і дорогою, тому починають формуватися нові правила ведення війни - неоголошеної та прихованої. Задля мінімізації втрат (як людських, так і матеріальних) війна переходить у інформаційну і віртуальну площину, а бойові дії використовуються виключно в моменти, коли їх вже неможливо не використовувати. Парадоксом гібридної війни виявився сам факт того, що демократія може бути слабкістю учасника конфлікту, що вступає в конфронтацію із авторитарною державою.

Якщо ж виходити із твердження, що гібридна війна - це війна інформаційного суспільства, то головним комунікатором і ретранслятором наративів агресора стають саме засоби масової інформації, соціальні мережі та Інтернет як основний інформаційно-комунікативний простір двадцять першого сторіччя. 2018 рік показав, що «фейкова» реальність стає все більше невід'ємною складовою сучасного життя, а поширення дезінформації, тролінгу тощо - це методи як державних, так і недержавних акторів (Белей, 2019). Дезінформація поширюється у формі 1) відвертих фейків, повністю вигаданих та таких, що не мають жодного фактичного підтвердження (неправда), 2) інформації, яка має фактичне підтвердження, може бути доведена, але до неї додаються фейкові елементи, тобто де неправда приховується в середині правди (напівправда), 3) перекрученої інформації, де певні акценти або ж головні тези зміщуються на потрібні агресору, наприклад, з позитивних аспектів на негативні (маніпулятивна правда).

Після поширення дезінформація покликана створити відповідну громадську думку, яка буде відповідати цілям агресора. Агресору цікаві вибори як процес, а тому йому не так важлива перемога на виборах якогось окремого конкретного (проросійського) кандидата, скільки доведення до абсурду самого процесу волевиявлення, що потягне за собою сумніви щодо 
результату такого волевиявлення. Відповідно, кінцевим результатом буде новостворена політична система без довіри виборця. Наративи, що «вкидаються» у інформаційне поле, повинні максимально дезорієнтувати виборця, поляризувати суспільство, а зрештою піддати сумніву ефективність виборчого процесу. Тому російська пропаганда може за допомогою різних каналів, подекуди протилежних за своєю «ідеологією», одночасно або критикувати усі політичні табори, або ж сприяти їм.

Останні прецеденти із виборами президента в США (BBC, 2017; Coats, 2019, р.7) або Франції (Daniels, 2017), Брекзіт (Booth and others, 2017), фінансування РФ праворадикальних і ліворадикальних партій в СС (Горбулін ред. 2017, с. 428-432], інформація про готовність РФ втрутитись в хід чергових виборів Президента України в 2019 році (Coats, 2019, p. 38) - це ознаки того, що Російська Федерація знайшла найболіснішу точку демократій Західного світу - демократичне волевиявлення, вибори та пов’язані 3 ними виборчі процеси. Відповідно, недемократична та авторитарна Російська Федерація перетворила демократію на головного ворога демократичної держави, де зброєю є основні демократичні цінності. Свобода слова перетворилася в необмежене право на поширення брехні, вільний доступ до інформації став безконтрольним потоком фейків i пропаганди, свобода на мирні зібрання стала правом на вуличні зіткнення. Це все і є тим контрольованим хаосом, який ослаблює об'єкт агресії, робить його вразливим до зовнішніх викликів та підриває зсередини.

Вищенаведені тези можна довести на прикладі останньої статті ідеолога концепції «суверенної демократії» та куратора маріонеткових «урядів» в окупованих Росією районах Донецької та Луганської областей Владислава Суркова (2019). Фактично, В. Сурков вказує, що головна зброя Російської Федерації - це вразливість західної демократії. Так, В. Сурков (2019) прямо називає демократію “ілюзією вибору, найважливішою з ілюзій, коронним трюком західного способу життя взагалі і західної демократії зокрема”. Саме «ілюзорністю» демократії В. Сурков обгрунтовує иiі 
непотрібність для Росії та заміну власним особливим шляхом розвитку. Ототожнюючи сучасну Росію виключно з В. Путіним, він вводить поняття «путінізму» як головної доктрини існування держави, що прийшла на заміну «марксизму», а також стверджує, що авторитаризм - єдина можлива російська політична реальність.

Далі він (Сурков, 2019) зазначає, що: «чужоземні політики приписують Росії втручання у вибори і референдуми по всій планеті. Насправді, справа ще серйозніше - Росія втручається в їх мозок, і вони не знають, що робити 3 власною зміненою свідомістю». Ця теза підкріплюється його наступним твердженням про те, що тепер Росія сама створює та поширює наративи, що $\epsilon$ своєрідним інформаційним наступом (який у статті називається контрнаступом). Результатом цього $є$ те, що європейські та американські експерти все більше помиляються у своїх прогнозах, а результати електоральних вподобань стають «паранормальными».

Дійсно, використано доволі влучний термін для характеристики буму популізму в останні роки - паранормальність. Російська Федерація, проводячи свою пропагандистську методичну роботу, спирається здебільшого на головну електоральну базу популістів - незахищені, малозабезпечені та малограмотні верстви населення, які є в більшості у будьякій державі і які, отримавши надзвичайно широкий та вільний доступ до інформації (в тому числі маніпулятивної), не здатні до критичного мислення і розглядають політичних акторів як ворогів, політичну еліту як контркультуру та джерело своїх негараздів. Фактично, тут Росія використовує напрацювання більшовизму, коли класова боротьба знову виходить на порядок денний.

Далі ж В. Сурков підтверджує ціль російської стратегії 3 підриву демократичного світу:

«Недовіра i заздрість, що використовуються демократією в якості пріоритетних джерел соціальної енергії, необхідним чином призводять до абсолютизації критики і підвищенню рівня тривожності. Хейтери, 
тролі і такі, що приєдналися до них злі боти утворили верескливу більшість, витіснивши з домінуючих позицій високоповажний середній клас, що колись задавав зовсім інший тон. У добрі наміри публічних політиків тепер ніхто не вірить, їм заздрять і тому вважають людьми порочними, лукавими, a то i прямо мерзотниками. Відомі політографічні серіали від «Боса» до «Карткового будиночка» відповідно малюють натуралістичні картини каламутних буднів істеблішменту» (Сурков, 2019).

Недовіра, хаос, делегітимізація політичної системи і політичних інститутів - це бажаний результат агресора, який досягається саме перекручуванням головних цінностей демократії. В. Сурков (2019) підтверджує, що, коли світ радісно зустрічав глобалізацію, Росія створила свою «суверенну демократію» 3 посиленою роллю націоналізму та шовінізму, який тепер експортує на Захід, адже: «англійський брекзіт, американський «\#грейтегейн», антиімміграційне огородження Європи лише перші пункти розлогого списку повсюдних проявів деглобалізації, ресуверенізаціі і націоналізму». А коли весь світ користувався благами Інтернету - Росія вирішила обернути доступність Інтернету в найлегший спосіб поширення дезінформації. В. Сурков (2019) констатує: «колись вільний віртуальний простір, розрекламований як прообраз майбутнього раю, захоплено і розмежовано кіберполіцією та кіберзлочинністю, кібервійськами i кібершпигунами, кібертерористами і кіберморалістамі». Дійсно, Інтернет став таким, бо Росія та їі ситуативні союзники (Китай, Іран тощо) заполонили його тролями, фейками і пропагандою, завчасно створивши в своїх країнах простір несвободи в Інтернеті. Тому В. Сурков називає останні російські інформаційні операції просто зміною кута зору, під яким західний виборець повинен дивитися на демократію - і розчаруватися в ній. А альтернативою він пропонує, звісно ж, суверенну демократію за російською моделлю, 3 народом рабів і мудрим лідером. Правда, В. Сурков не вживає термін «народ рабів», він використовує поняття «глибинний народ». 
Помічник президента РФ закінчує свої роздуми щодо майбутнього путінізму та Росії так:

«У нашої нової держави в новому столітті буде довга і славна історія.

Вона не зламається. Буде діяти на по-своєму, отримувати і утримувати призові місця у вищій лізі геополітичної боротьби. 3 цим рано чи пізно доведеться змиритися всім тим, хто вимагас, щоб Росія «змінила поведінку». Адже це тільки здасться, що вибір у них с» (Сурков, 2019).

Це пряма погроза - відкрита і неприхована. Це натяк, що Росія не збирається зупинятися, а тому Свропі потрібно замислитися і зрозуміти, що Україна - лише перша жертва «нового та дивного світу», але світу не Хакслі, а Путіна. Європа буде наступною, адже на одному континенті не зможе ужитися демократичне співтовариство i недемократична держава 3 нереалізованим комплексом імперії.

Висновки i перспективи подальших досліджень. Підсумовуючи вищевикладене, в такому випадку постає питання, як врятувати демократію в умовах гібридної війни. Якщо не здійснювати превентивних заходів, то адептами гібридної війни демократичні процедури перетворяться на зброю проти самої демократії. I, врешті, така демократія погубить західний світ, штовхне у вир популізму та внутрішньої поляризації. Можна, звісно, посилювати кібербезпеку, медіаграмотність населення, створювати think tanks (аналітичні центри), проводити наради та тренінги. Але головний недолік демократії полягає в тому, що демократія не встигає реагувати на асиметричні дії авторитарного агресора, він завжди на крок попереду. Можна уподібнитися агресору та зрадити демократичним цінностям. Цей варіант неприйнятний, і він все одно не врятує від конфлікту, адже Росії не потрібні конкуренти.

Демократію врятує тільки загальноєвропейська та загальносвітова солідарність, створення ефективної коаліції 3 деконструкції та ліквідації авторитарного режиму, що становить загрозу світові. I поки є шанс зробити 
це шляхом рішучого, але поступового посилення санкцій. Зараз лише Україна платить життями своїх громадян, але, якщо нічого не робити, обов’язково настане час, і європейці теж будуть вимушені віддавати життя за волю і демократію.

\section{ЛІТЕРАТУРА}

1. Адміністрація Президента України, 2012. Указ Президента Украӥни №390/2012 «Про рімення Ради начіональної безпеки і оборони Украӥни від 8 червня 2012 року «Про нову редакиію Воєнної доктрини Украӥни». [online] Доступно: https://www.president.gov.ua/documents/3902012-14403 [Дата звернення 23 січень 2019].

2. Андрієвський, Т., 2018. Цілі російсько-української гібридної війни. Політичне життя, [online] 2, с.103-108. Доступно: http://jpl.donnu.edu.ua/article/view/5961 [Дата звернення 23 січень 2019].

3. Белей, Л. 2019. Fake it until you fake it! UCHOOSE. [online] Доступно: http://uchoose.info/fake-it-until-you-fake-it/?fbclid=IwAR2bIdPC1YiWxpXk9hyZ1Tp52MTw4czyycRGTUnVFjcM3I8G3N6omuJQdA [Дата звернення 20 січень 2019].

4. Герасимов, В., 2015. По опыту Сирии. Военно-промышленный курьер, [online] Доступно: http://vpk-news.ru/articles/29579 [Дата звернення 23 січень 2019].

5. Горбулін, В.П. ред., 2017. Світова гібридна війна: украӥнський фронт. Харків: Фоліо.

6. Даглас, Н., 2000. Інституиіï, інституційна зміна та функиіонування економіки. Переклад з англійської І. Дзюб. Київ: Основи.

7. Рущенко, I. 2015. Російсько-украйнська гібридна війна: погляд соиіолога. Харків: ФОП Павленко О. Г.

8. Сурков, В., 2019. Долгое государство Путина. Независимая Газета, [online] Доступно: http://www.ng.ru/ideas/2019-02-11/5_7503_surkov.html [Дата звернення 11 лютий 2019].

9. BBC, 2017. Russia-linked posts 'reached 126m Facebook users in US'. [online] (Last updated 31 October 2017) Available at: http://www.bbc.com/news/world-us-canada41812369 [Accessed 23 January 2019].

10. Booth, R., Weaver, M., Hern, A. and Walker, S., 2017. Russia used hundreds of fake accounts to tweet about Brexit, data shows. The Guardian, [online] Available at: https://www.theguardian.com/world/2017/nov/14/how-400-russia-run-fake-accountsposted-bogus-brexit-tweets [Accessed 23 January 2019].

11. Coats, D.R., 2019 Worldwide threat assessment of the US intelligence community. [online] Available at: https://www.intelligence.senate.gov/sites/default/files/documents/os-dcoats012919.pdf?fbclid=IwAR3pcMsWpEabsyWqDifHT6SUVHgHdqzFwsij78H7gsz9Bg5e04 rbKtMrilI [Accessed 23 January 2019].

12. Daniels, L., 2017. How Russia hacked the French election. POLITICO, [online]. Available at: $\quad$ https://www.politico.eu/article/france-election-2017-russia-hacked-cyberattacks [Accessed 23 January 2019]. 


\section{Інформація про автора}

Андрісвський Тимур Григорович - аспірант кафедри політології, соціології і культурології Харківського національного педагогічного університету ім. Г.С. Сковороди; e-mail: andrievskytimur@gmail.com; ORCID: http://orcid.org/0000-0001-9602-5154.

Стаття надійшла до редакції: 13.02.2019 р. $\quad$ Прийнята до друку: 22.02.2019 p. 